\title{
Designed Education Program for Nurses about Immediate and Long Term Nursing Management of Patient with Status Asthmaticus in El-Mobara Hospital at Assiut Governorate
}

\author{
Naglaa Fathy Yousif ${ }^{1}$, Olfat MOstafa El Shinawy ${ }^{2}$, Enas Abd El Mageed Daef ${ }^{3}$ \& Olfat Abd Al-Ghany El- \\ Shafiey ${ }^{4}$. \\ 1. Nursing Specialist in Almbra Hospital of Assiut Health Insurance, Egypt. \\ 2. Professor of Chest Disease, Faculty of Medicine, Assiut University, Egypt. \\ 3. Assistant Professor of Micor Biology and Immunology Faculty of Medicine, Assiut University, Egypt. \\ 4. Professor of Critical Care Nursing, Faculty of Nursing, Assiut University, Egypt.
}

\begin{abstract}
Aim of this study was to evaluate the effect of the designed education program on nurses' knowledge regarding immediate and long term management of patient with status asthmaticus. Design: A Qusi experimental research design was utilized in this study on a convenient sample of 30 nurses working at El -Mobara hospital. Data collection tools was; Nurse's Knowledge Questionnaire sheet, consisted from three parts part 1) demographic characteristics, part 2) knowledge assessment about status asthmaticus and part 3) assessment of immediate and long term management. In addition, designed education program. Results: The majority of them their age ranged from 20 -40 years. Majority of nurses had knowledge regarding care of patients with status asthmaticus at satisfactory level in post-test .while all of nurses had no knowledge regarding nursing care of bronchial asthma in pre-test. The study Concluded that application of designed education program for nurses about immediate and long term nursing management of patient with status asthmaticus was associated with significant improvements of nurses' knowledge. Therefore, the Researchers Recommended making a standardized written nursing care and training programs for nurses in asthmatic care to ensure high quality of information and care provided based on national and international standards.
\end{abstract}

\section{Keywords: Education Program, Immediate, Long Term, Nursing Management \& Status Asthmaticus.}

\section{Introduction}

Asthma is a chronic lung disease in which air passages get inflamed. When this happens, airways narrow and it is difficult for air to move from the nose and mouth to the lungs This disease affects millions of people In fact, all ages and races and both sexes. However; asthma is more common in adults and alders. It is also more common in African, Americans and Hispanics than whites (National Heart Lung \& Blood Institute, 2011)

It is a chronic inflammatory disorder of the airways in which many cells and cellular elements play a role. The chronic inflammation can be associated with airway hyper-responsiveness, that leads to recurrent episodes of wheezing, breathlessness, chest tightness, and coughing, particularly at night or in the early morningThese episodes are usually associated with widespread or variable airflow obstruction within the lung (Koolwal, et al., 2014).

The most common cause of asthma results from allergic hyper-responsiveness of the trachea and bronchi to irritants. The precipitating factors include viral infection, air pollution, dust, molds, Pollen, certain foods, physical and physiological stress (Irene \& Evette, 2015).
Asthma symptoms are dyspnea, wheezing in the chest, and repeated coughing episodes, wheezing is the most common sign of asthmatic patients. In general, a family history of allergies is an important indication, directing the diagnosis towards allergic asthma (Saadeh, et al., 2015).

Status asthmaticus is an acute exacerbation of asthma that remains unresponsive to initial treatment with bronchodilators. Status asthmaticus can vary from a mild form to a severe form with bronchospasm, airway inflammation, and mucus plugging that can cause difficulty breathing; carbon dioxide retention; hypoxemia; and respiratory failure. Patients report chest tightness, rapidly progressive shortness of breath, dry cough, and wheezing and may have increased their beta-agonist intake (nebulizer) to as often as every few minutes. (Fehrenbach et al., 2017).

Respiratory failure results in hypoxia, carbon dioxide retention and acidosis. The exact mechanism underlying the development of an acute severe asthma attack remains elusive but there appear to be two phenotypes. (Thenaruvi et al., 2019).

Gradual-onset in about $80 \%$ severe attacks develop over more than 48 hours. Sudden-onset often in 
association with significant allergen exposure. Patients tend to be older and to present between midnight and $8 \mathrm{am}$. This type of attack is associated with neutrophilic inflammation and a swifter response to therapy these are associated with eosinophilic infiltration and slow response to therapy (Antonioli et al., 2019).

Risk factors: Inadequately treated disease inadequate medical monitoring. Inappropriate beta-blocker prescription or heavy sedation. Non-steroidal antiinflammatory sensitivity. Use of a long-acting beta 2 agonist such as salmotrol, especially if not using a steroid inhaler. Personal or passive smoking. Environmental conditions air pollution (ozone, sulphur dioxide, nitrogen dioxide and particulates) and pollen levels are thought to influence the rate of hospital admissions. Sensitivity to fungi (severe asthma with fungal sensitization (SAFS). (Singh, 2017).

Adverse behavioural / psychosocial factors: Noncompliance, frequent failure to attend appointments, self-discharge, denial of illness. Psychiatric illness (psychosis, depression), alcohol or street drug use. (Silva \& Moreira, 2017)

Patient education is a non-pharmacologic tool that nurses should use education: begin at the time of diagnosis and continue through all the follow-up visits asthma cannot be controlled at a distance, so physicians and other healthcare providers must enable their patients to manage the disease minute-by-minute and day-by-day. Along with a written treatment plan, physicians should give their patients (George et al., 2016).

Nurses perform a variety of vital functions in asthma care, including asthma education in the primary care setting and in hospitals and other community settings, care of the patient with asthma in the acute care setting, ambulatory care, and intensive care. Nurses also obtain information on how asthma affects the patient's every day activities and self-concept, the patient's and family adherence to the prescribed therapy, and their personal statement goals (Wang et al., 2017).

Asthma is affecting more than 334 million people worldwide. It is the most common chronic lung disease, affects 8-10\% of persons in urban area and 5$8 \%$ in rural area. (Vedanthan et al., 2016). More than $50 \%$ of asthma cases are found any ages. (Louis and Helen, 2014). There are almost $8.6 \%$ from young and adult reporting asthma symptoms in Africa (Hassan \& El-awady, 2015).

\section{Significance of the study}

Status athmaticus is the most common chronic disease. It can cause considerable burden on the physical, social, emotional, and professional lives of affected individuals and family. There are a fewer number of researches about status asthmaticus nursing care given, so that information obtained from this education program help the pediatric nurses and other health professional to gain knowledge regarding the immediate and long term nursing management of patient with status asthmaticus.

\section{Aim of the study}

To evaluate the effect of designed education program on nurses' knowledge regarding immediate and longterm management of patient with status asthmaticus.

\section{Research Hypothesis}

To fulfill the aim of the study the following research hypothesis was formulated:

The post test mean knowledge scores of the nurses who will receive the designed education program will be higher than their pre-test mean knowledge scores.

\section{Subjects \& Methods}

Quasi-experimental research design has been utilized in this study.

\section{Study sample}

A convenience sample including all available nurses (30) nurses as (3) male and (17) female working at Emergency department and (10) nurses at Internel Chest Medical department all are willing to participate in the study. Their age ranged between (19-45) years who are currently assigned and provide care for patients.

\section{Study variables}

The independent variable in this study was the designed education program while the dependent variables are nurse's knowledge.

\section{Study setting:}

The study was conducted in emergency and chest department at El-Mobara Hospital, at Assiut Government.

\section{Tools of data collection}

One tool was developed by the researcher to collect the necessary data for this study as the following:

\section{Tool I: Structured interview questionnaire sheet}

It was developed by the researcher after reviewing the relatives and literatures. It was translated to simple Arabic language to assess exact nurse knowledge about status asthmaticus. It was used prior to implementation of the education program. The same tool was used immediately after the implementation of the training program (immediate post-test) in addition to after three months then three months later to evaluate the gain in knowledge after the intervention. It consisted of three parts:

Part (1): Include demographic data (e.g., age. gender, marital status, educational level, years of experience 
and pervious attended training, ect).

Part (2): Used to assess nurses' knowledge about status asthmaticus. It includes 15 items as the following: Define status asthmaticus their clinical symptoms, triggers, ect.. It included 15 questions.

Part (3): Used to assess nurses knowledge about immediate and long term management of patient with asthma include questions from (16 to 30).

- The structured interview questionnaire sheet was filled out by the researcher from nurses who answered all its components then collected during theinterview.

- The total number of questions was 30

\section{Scoring system}

For part (2): each complete answer got score of (2) and incomplete answer got score of (1) but unknown answer got score of (0).

Maximal score of (60) had been obtained for answering correctly all, while a minimal score of (0) had been otherwise obtained.

For part (3): each completely correct answer was got score of (2) and incorrect item was get score of (0) maximal score of (60) had been obtained for answering correctly all, while a minimal score of (0) had been otherwise obtained.

- The total number of questions was (30). The total scores were (60).

- Nurses who scored (70\%) or more were considered as having "very good" knowledge.

- Those who scored $(60 \%$ - $70 \%)$ were considered as having "good" knowledge

- Those scored $(50 \%$ - $60 \%)$ were considered as having "pass" knowledge,

- less than $50 \%$ were considered 'poor.

Designed education program

The content of designed education program was developed by the researcher based on nurses' needs, current national and international literature review, researcher experience and opinions. All medical and nursing expertise based on; data of National association of thoracic, (2010); Global Initiative for asthma, (2014). American Journal of Respiratory and Critical Care Medicine, and nursing Guidelines for assessing and managing asthma risk at work,.

The designed education program booklet was revised and modified based on the expertise comments. It was written in Arabic using simple language with illustrations and was modified by the investigator. It was concerning knowledge about preif illustration of the respiratory system, identification asthma and triggers, complications, treatment and long term management concerning basic skills for nurses working with patients who has asthma attack, nurses' roles during parenteral and intramuscular medication, observation, follow up and discharge notes.
Operational design Procedure: This study was carried out on three phases

1-The preparatory phase ( $1^{\text {sl }}$ phase)

Preparation of tools for data collection and program was done during this phase. It was formulated after reviewing of literature using books, articles, periodicals and magazines. This was followed by arranging for the education program schedule based on the resources available.

\section{Content validity}

It was established by panel of seven expertise from the respiratory, emergency and thoracic nursing staff who reviewed the instruments for clarity and relevance.

\section{Pilot study}

It was carried out in October 2015, on 30 nurses working with patients with asthma. They were chosen randomly from emergency and internal respiratory departments at El-Moubra Hospital to test visibility and applicability of the tools and to estimate the time required for interview. Some minor modifications based on the result of the pilot study were made to have more applicable tools for data collection. Some statements were omitted, added or rephrased, and then the final forms were developed, so the $10 \%$ of the subjects selected for the pilot study were excluded from this study. The total number of nurses was 30 .

2-Implementation phase: $\left(2^{\text {nd }}\right.$ phase)

Before conducting the actual study, an official permission was obtained and the purpose of the study was explained to all nurses. At initial interview the researcher introduce herself to initiate line of communication, explain the nature and purpose of the teaching protocol and asked nurses to fill out the questionnaire sheet (tool I ) to assess nurse's knowledge before application of the designed education program also she scheduled with the nurses the teaching sessions for both theory and practice and the nurses were divided into small groups or according to their workload, each group contains 10 nurses.

Group of nurses was given the freedom to choose their optimal time for receiving the teaching program whenever they have minimal workload, Tool I (part 2 and 3) were used before and immediately alter the implementation of the designed education program as well as three and nine months later to evaluate the impact of the designed education program on nurses' knowledge.

\section{Designed Education program sessions}

The educational program had been implemented for nurses in terms of sessions and teaching on the spot during their official working hours. Program was aided by using; posters and handout about the care of patient with asthma. There were a total of six sessions 
in addition to pre assessment session. These six sessions were repeated 10 times to each group. Four knowledge sessions, based on the nurses needs for knowledge about asthma. The duration of each knowledge session was one hour including 15 minutes for discussion and feedback.

These were followed by two practice sessions; the duration of each session was two hour with break in. Each session usually included summary of what has been taught during the previous sessions and the objectives of the new topics. Feedback and reinforcement of teaching was performed according to the nurses needs to ensure their understanding. Giving praise and/or recognition to the interested nurses were emphasized for motivation during the teaching program implementation. Each nurse obtained a copy of the teaching program booklet that included all the training contents.

\section{3-Evaluation phase: $\left(3^{\text {rd }}\right.$ phase $)$}

The last phase of proposed teaching program is the evaluation phase. In which the nurse's knowledge were evaluated immediately by the researcher after program implementation as well as after three and nine months later through filling the tool I (parts 2 and $3)$.

\section{Administrative Design}

Official permissions to conduct the study were obtained from the directors and the head nurses of internal respiratory and emergency department at ElMobara Hospitals. Meeting with nursing supervisors and physicians were done to explain the objectives, contents of the training program and the methods for application of the education program to gain their cooperation.

\section{Ethical consideration}

Informed consent was obtained from the nurses who are willing to participate in the study after explanation of the nature and purposes of the study. Confidentiality of the subjects was certainly assured and they were given the right to the nurse to withdraw from this study at any time.

\section{Statistical Design}

The collected data were coded then transformed into specially designed form so as to be suitable for entering into IBM compatible computarised entered data were verified for any errors using Statistical Packing for Social Sciences (SPSS) version (7) for windows. The following tests for significance were used frequency, percentage, means and standard deviation, correlation coefficient and ANOVA. Using of test for comparison of means and to determine significant for numeric variables. A probability level of 0.05 was adopted as a level of significance for testing the research hypothesis. Statistical significance was considered at $\mathrm{p}$-value $<0.05, \mathrm{P}<0.01$ moderate significant, ( $\mathrm{P}>0.05)$ non significant and $<0.001$ highly significant. 


\section{Results}

Table (1): Personal characteristics of the studied nurses.

\begin{tabular}{|c|c|c|}
\hline & No. $(n=30)$ & $\%$ \\
\hline \multicolumn{3}{|l|}{ Job: } \\
\hline Nurse & 26 & 86.7 \\
\hline Head nurse & 4 & 13.3 \\
\hline \multicolumn{3}{|l|}{ Age: (years) } \\
\hline$<30$ years & 14 & 46.7 \\
\hline$\geq 30$ years & 16 & 53.3 \\
\hline \multicolumn{3}{|l|}{ Level of education: } \\
\hline Diploma of Nursing & 22 & 73.3 \\
\hline Technical Institute of Nursing & 4 & 13.3 \\
\hline Bachelor of Nursing & 4 & 13.3 \\
\hline \multicolumn{3}{|l|}{ Marital status: } \\
\hline Single & 2 & 6.7 \\
\hline Married & 27 & 90.0 \\
\hline Widow & 1 & 3.3 \\
\hline \multicolumn{3}{|l|}{ Years of experience: } \\
\hline$<15$ years & 17 & 56.7 \\
\hline$\geq 15$ years & 13 & 43.3 \\
\hline \multicolumn{3}{|l|}{ Working in another place: } \\
\hline Yes & 7 & 23.3 \\
\hline No & 23 & 76.7 \\
\hline \multicolumn{3}{|c|}{ Years of experience in current place: } \\
\hline$<15$ years & 18 & 60.0 \\
\hline$\geq 15$ years & 12 & 40.0 \\
\hline \multicolumn{3}{|l|}{ Attending training courses: } \\
\hline Yes & 17 & 56.7 \\
\hline No & 13 & 43.3 \\
\hline \multicolumn{3}{|l|}{ Trainers: } \\
\hline Nursing specialist & 13 & 76.5 \\
\hline Nursing specialist and physician & 4 & 23.5 \\
\hline \multicolumn{3}{|l|}{ Regularity of training: } \\
\hline Regular & 14 & 82.4 \\
\hline Irregular & 3 & 17.6 \\
\hline
\end{tabular}


Table (2): Nurses knowledge about status asthmaticus.

\begin{tabular}{|c|c|c|c|c|c|}
\hline & \multicolumn{2}{|c|}{$\begin{array}{c}\text { Pre-test } \\
(n=30)\end{array}$} & \multicolumn{2}{|c|}{$\begin{array}{c}\text { Post-test } \\
(n=30)\end{array}$} & \multirow[t]{2}{*}{ P-value } \\
\hline & No. & $\%$ & No. & $\%$ & \\
\hline \multicolumn{5}{|l|}{ Definition of status asthmaticus: } & \multirow{4}{*}{$0.000 *$} \\
\hline Incorrect & 7 & 23.3 & 0 & 0.0 & \\
\hline Incomplete correct & 18 & 60.0 & 5 & 16.7 & \\
\hline Complete correct & 5 & 16.7 & 25 & 83.3 & \\
\hline \multicolumn{6}{|l|}{ Signs and symptoms: } \\
\hline Dyspnea-tachypnea & 28 & 93.3 & 30 & 100.0 & 0.472 \\
\hline Flushing face & 1 & 3.3 & 24 & 80.0 & $0.000 *$ \\
\hline Wheezing & 2 & 6.7 & 18 & 60.0 & $0.000 *$ \\
\hline Heavy sweating- fatigue & 16 & 53.3 & 23 & 76.7 & 0.058 \\
\hline Cyanosis if patient deteriorated & 4 & 13.3 & 23 & 76.7 & $0.000 *$ \\
\hline Persistent cough & 8 & 26.7 & 19 & 63.3 & $0.004 *$ \\
\hline Increase mucus secretion & 5 & 16.7 & 9 & 30.0 & 0.222 \\
\hline \multicolumn{6}{|l|}{ Trigger of asthma: } \\
\hline Don't know & 3 & 10.0 & 0 & 0.0 & 0.236 \\
\hline $\begin{array}{l}\text { Exposure to dust and animal fur-chemical substances } \\
\text { and polnes }\end{array}$ & 26 & 86.7 & 29 & 96.7 & 0.350 \\
\hline Heavy exercise & 1 & 3.3 & 25 & 83.3 & $0.000 *$ \\
\hline Non-steroid and anti-inflammatory drugs (Aspirin) & 1 & 3.3 & 23 & 76.7 & $0.000 *$ \\
\hline Exposure to psychological stress & 0 & 0.0 & 24 & 80.0 & $0.000 *$ \\
\hline Viral or bacterial infection & 4 & 13.3 & 21 & 70.0 & $0.000 *$ \\
\hline Smoking & 8 & 26.7 & 16 & 53.3 & $0.035 *$ \\
\hline \multicolumn{5}{|l|}{ Dangers of the disease: } & \multirow{4}{*}{$0.000 *$} \\
\hline Incorrect & 13 & 43.3 & 4 & 13.3 & \\
\hline Incomplete correct & 14 & 46.7 & 6 & 20.0 & \\
\hline Complete correct & 3 & 10.0 & 20 & 66.7 & \\
\hline \multicolumn{6}{|l|}{ Dealing with the patient: } \\
\hline Don't know & 4 & 13.3 & 1 & 3.3 & 0.350 \\
\hline Improve the respiration for patient & 15 & 50.0 & 27 & 90.0 & $0.001 *$ \\
\hline Encourage the patient to make spontaneous Respiration & 2 & 6.7 & 27 & 90.0 & $0.000 *$ \\
\hline Correct the narrowing of air way & 1 & 3.3 & 23 & 76.7 & $0.000 *$ \\
\hline Follow infection control instruction & 10 & 33.3 & 28 & 93.3 & $0.000 *$ \\
\hline \multicolumn{6}{|l|}{ Diagnosis of asthma: } \\
\hline Don't know & 11 & 36.7 & 0 & 0.0 & $0.000 *$ \\
\hline History of disease & 2 & 6.7 & 27 & 90.0 & $0.000 *$ \\
\hline Clinical examination & 6 & 20.0 & 20 & 66.7 & $0.000 *$ \\
\hline Chest X-ray & 14 & 46.7 & 29 & 96.7 & $0.000 *$ \\
\hline Respiratory function test & 1 & 3.3 & 24 & 80.0 & $0.000 *$ \\
\hline Blood gases & 4 & 13.3 & 24 & 80.0 & $0.000 *$ \\
\hline Laboratory test & 4 & 13.3 & 11 & 36.7 & $0.037 *$ \\
\hline Sputum culture & 0 & 0.0 & 16 & 53.3 & $0.000 *$ \\
\hline
\end{tabular}


Table (3): Nurses knowledge about Long-term management of patient with status asthmaticus

\begin{tabular}{|c|c|c|c|c|c|}
\hline & \multicolumn{2}{|c|}{$\begin{array}{c}\text { Pre-test } \\
(n=30)\end{array}$} & \multicolumn{2}{|c|}{$\begin{array}{c}\text { Post-test } \\
(n=30)\end{array}$} & \multirow[t]{2}{*}{ P-value } \\
\hline & No. & $\%$ & No. & $\%$ & \\
\hline \multicolumn{6}{|l|}{ Methods of drug intake } \\
\hline Don't know & 1 & 3.3 & 0 & 0.0 & 0.313 \\
\hline Inhalation & 25 & 83.3 & 30 & 100.0 & 0.062 \\
\hline Injection & 25 & 83.3 & 29 & 96.7 & 0.197 \\
\hline Oral & 20 & 66.7 & 25 & 83.3 & 0.136 \\
\hline \multicolumn{6}{|c|}{ Things that the patient must avoid it? } \\
\hline Don't know & 1 & 3.3 & 0 & 0.0 & 0.313 \\
\hline Smoking & 29 & 96.7 & 30 & 100.0 & 0.313 \\
\hline Dust & 3 & 10.0 & 30 & 100.0 & $0.000 *$ \\
\hline Excessive exercise & 0 & 0.0 & 27 & 90.0 & $0.000^{*}$ \\
\hline Psychological stress & 0 & 0.0 & 18 & 60.0 & $0.000 *$ \\
\hline Cold environment & 0 & 0.0 & 11 & 36.7 & $0.000 *$ \\
\hline Drugs that cause asthma & 0 & 0.0 & 5 & 16.7 & 0.062 \\
\hline \multicolumn{6}{|c|}{ Exercises which improve breathing and prevent asthma attack } \\
\hline Don't know & 19 & 63.3 & 1 & 3.3 & $0.000 *$ \\
\hline Coughing and breathing exercise & 11 & 36.7 & 27 & 90.0 & $0.000 *$ \\
\hline Yoga & 0 & 0.0 & 27 & 90.0 & $0.000 *$ \\
\hline Walking & 0 & 0.0 & 25 & 83.3 & $0.000 *$ \\
\hline Tennis table & 0 & 0.0 & 14 & 46.7 & $0.000 *$ \\
\hline \multicolumn{6}{|c|}{ Food that improve breathing and prevent asthma attack } \\
\hline More than one answer & 6 & 20.0 & 0 & 0.0 & $0.031 *$ \\
\hline Fresh fruits and vegetables & 16 & 53.3 & 29 & 96.7 & $0.000^{*}$ \\
\hline Hot drinks (tea, feverfew, ginger) & 12 & 40.0 & 30 & 100.0 & $0.000 *$ \\
\hline Onions and garlic & 3 & 10.0 & 26 & 86.7 & $0.000 *$ \\
\hline Honey & 0 & 0.0 & 18 & 60.0 & $0.000 *$ \\
\hline Fish oil & 0 & 0.0 & 18 & 60.0 & $0.000 *$ \\
\hline Food contain calcium & 1 & 3.3 & 5 & 16.7 & 0.197 \\
\hline \multicolumn{6}{|l|}{ Food must be avoided } \\
\hline More than one answer & 3 & 10.0 & 0 & 0.0 & 0.236 \\
\hline Milk & 19 & 63.3 & 30 & 100.0 & $0.000 *$ \\
\hline Egg & 12 & 40.0 & 29 & 96.7 & $0.000 *$ \\
\hline Salt & 3 & 10.0 & 27 & 90.0 & $0.000 *$ \\
\hline Peanuts & 0 & 0.0 & 26 & 86.7 & $0.000 *$ \\
\hline Fish & 5 & 16.7 & 17 & 56.7 & 0.001 \\
\hline Preservatives & 1 & 3.3 & 9 & 30.0 & $0.006 *$ \\
\hline Saturated fats & 1 & 3.3 & 14 & 46.7 & $0.000 *$ \\
\hline
\end{tabular}

Table (4): Level of knowledge of the studied nurses in pre-test and post-test

\begin{tabular}{|c|c|c|c|c|c|}
\hline \multirow[t]{2}{*}{ Knowledge } & \multicolumn{2}{|c|}{$\begin{array}{c}\text { Pre-test } \\
(n=30)\end{array}$} & \multicolumn{2}{|c|}{$\begin{array}{c}\text { Post-test } \\
(n=30)\end{array}$} & \multirow[t]{2}{*}{ P-value } \\
\hline & No. & $\%$ & No. & $\%$ & \\
\hline Unsatisfactory & 30 & 100.0 & 2 & 6.7 & \multirow{2}{*}{$<0.001 *$} \\
\hline Satisfactory & 0 & 0.0 & 28 & 93.3 & \\
\hline Mean \pm SD & \multicolumn{2}{|c|}{$21.57 \pm 3.78$} & \multicolumn{2}{|c|}{$62.17 \pm 8.27$} & $<0.001 *$ \\
\hline
\end{tabular}




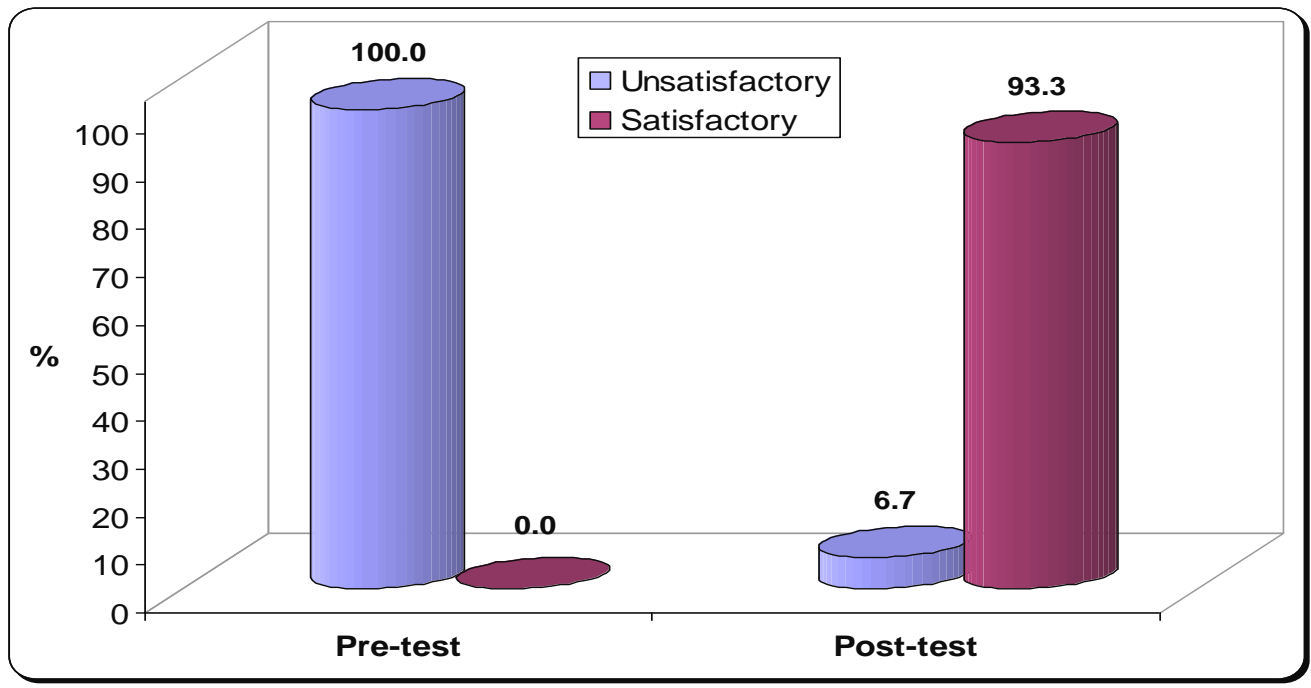

Figure (1): Level of knowledge of the studied nurses in pre-test and post test.

Table (5): Score of knowledge according to personal characteristics in post-test.

\begin{tabular}{|c|c|c|c|}
\hline & \multicolumn{2}{|c|}{ Knowledge } & \multirow{2}{*}{ P-value } \\
\hline & Mean \pm SD & Range & \\
\hline \multicolumn{3}{|l|}{ Age: (years) } & \multirow{3}{*}{0.574} \\
\hline$<30$ years & $61.25 \pm 7.40$ & $48-76$ & \\
\hline$\geq 30$ years & $62.78 \pm 8.96$ & $34-73$ & \\
\hline \multicolumn{3}{|l|}{ Level of education: } & \multirow{4}{*}{0.296} \\
\hline Diploma of Nursing & $62.71 \pm 9.05$ & $34-76$ & \\
\hline Technical Institute of Nursing & $58.00 \pm 5.40$ & $48-63$ & \\
\hline Bachelor of Nursing & $66.67 \pm 3.79$ & $64-71$ & \\
\hline \multicolumn{3}{|l|}{ Years of experience: } & \multirow{3}{*}{0.960} \\
\hline$<15$ years & $62.24 \pm 7.01$ & $48-76$ & \\
\hline$\geq 15$ years & $62.08 \pm 9.99$ & $34-73$ & \\
\hline \multicolumn{3}{|l|}{ Working in another place: } & \multirow{3}{*}{0.992} \\
\hline Yes & $62.20 \pm 4.32$ & $56-67$ & \\
\hline No & $62.16 \pm 8.92$ & $34-76$ & \\
\hline \multicolumn{3}{|c|}{ Years of experience in current place: } & \multirow{3}{*}{0.792} \\
\hline$<15$ years & $62.50 \pm 6.90$ & $48-76$ & \\
\hline$\geq 15$ years & $61.67 \pm 10.32$ & $34-73$ & \\
\hline \multicolumn{3}{|l|}{ Attending training courses: } & \multirow{3}{*}{$0.013^{*}$} \\
\hline Yes & $66.07 \pm 5.34$ & $60-76$ & \\
\hline No & $58.75 \pm 8.99$ & $34-73$ & \\
\hline
\end{tabular}

Table (1): This table showed that $53.3 \%$ of the studied nurses aged $\geq 30$ years, less than threequarters $(73.3 \%)$ had diploma of nursing, $90 \%$ of them were married. Also, this table illustrates that $40 \%$ of the studied nurses have more than 15years of experience and $56.7 \%$ of them attended training courses.

Table (2): presented nurses knowledge about status asthmaticus. This table shows that $16.7 \%$ of the studied nurses had complete correct answer about definition of disease in pre-test versus $83.3 \%$ in post- test with statistical significant difference. Regarding signs and symptoms, there were significant increases in post-test than in pre-test regarding flushing face, wheezing, cyanosis and persistent cough. Regarding trigger of asthma, it is clear that the nurses had higher knowledge in post-test than in pre-test with statistical significant differences in all items except "Exposure to dust and animal fur, chemical substances and pollens". Also, this table shows significant increases in post-test than in pre-test regarding knowledge of 
dangers of the disease, all items of dealing with the patient and diagnosis of asthma.

Table (3): This table showed nursing management for patients with status asthmaticus. There was statistical significant differences between pre-test and post-test regarding all items of immediate nursing management except in "Position of the sensor of the pulse oximeter on the client to obtain an accurate measurement".

Table (4): Showed nurses knowledge regarding longterm management for patients with status asthmaticus. There were statistical significant differences between pre-test and post-test regarding "Things that the patient must avoid them", "Exercise which improve breathing and prevent asthma attack", "Foods that improve breathing and prevent asthma attack", and "Food that must be avoided", while there was no statistical significant differences regarding "Methods of drug intake".

Table (5) \& Figure (1): Showed level of knowledge of the studied nurses in pre-test and post-test. It was found that all nurses had unsatisfactory knowledge in pre-test, while $93.3 \%$ of them had satisfactory knowledge in post-test with statistical significant difference $(\mathrm{P}<0.001)$. Also, it was found that the mean score of knowledge was higher in post-test $(62.17 \pm$ 8.27) than in pre-test $(21.57 \pm 3.78)$, with statistical significant difference $(\mathrm{P}<0.001)$.

Table (6) Showed score of knowledge according to personal characteristics in post-test. There is no statistical significant differences between scores of knowledge regarding age groups, level of education, years of experience, working in another place, years of experience in current place. While it was found that the mean score of knowledge was higher and statistically significant in nurses who attended training courses than nurses who didn't attend $(66.07 \pm 5.34$ and $58.75 \pm 8.99$ respectively) $(\mathrm{P}=0.013)$.

\section{Discussion}

The aim of the present study was to evaluate the effect of designed education program on nurses' knowledge regarding care of patient with status asthmaticus and provide a good nursing care for patient with status asthmaticus.

Status asthmatus is severe continuing attack of asthma that fails to respond to conventional drug therapy. It can last for days to weeks; even with optimal therapy, it may be fatal. (Smeltzer et al., 2010)

The nurse is responsible and accountable for the quality of nursing care given to patients. The single most important protective strategy for the patient is to be knowledgeable and safe practitioner of nurse. (Shah, 2009)

Nurses perform a variety of vital functions in asthma care, including asthma education in the primary care setting and in hospitals and other community settings, care of the patient with asthma in the acute care setting, ambulatory care, and intensive care. Nurses also obtain information on how asthma affects the patient's everyday activities and self-concept, the patient's and family adherence to the prescribed therapy, and their personal statement goals (Flinter et al., 2017).

The discussion will cover the main result findings as follow:

I.Demographic characteristics of studied nurses.

The result of the present study, about half of the nurses had their age $>30$ years and majority of them were females. As regarding level of education above two third of the study nurses had diploma degree and above half number of them had experiences < 15 years. All of the nurses had no in service training course related immediate and long term care of status asthmaticus but attending training in other fields as (Quality and Infection control)

The previous result is contradicted with David, (2012) who stated that continuing professional development by education and training after the qualification and or registration help nurses in improvement of patient care and enables professional nurse practitioners to provide quality nursing care and service delivery to their patients.

Nurses and other professional health caregivers should educate asthma patients the updated selfmanagement skills, knowledge, and guide the correct medicine approach, by using different teaching methods according to patients' condition to improve their quality of life (Qiu et al., 2017).

\section{Nurses' knowledge regarding status asthmaticus}

The result of this study revealed that; most of nurses had satisfactory level of knowledge as regarding status asthmatius.

The researcher opinion this result due to absence of nursing coreculum detailed content regarding status asthmaticus and, perhaps one of the most obvious indicators of the lack knowledge exhibited by the nurse is the confusion that exists surrounding roles and command structure.

This finding agrees with Albarraq, (2019) who found that, health care givers for asthmatic patients need continuous training and education about ashtma and emergency care.

The results of this study revealed that, nurses who had three to seven years only of experience had satisfactory level of knowledge. This item supported by Ameen, \& Abdullah, (2017) who found that, a lower level of knowledge among nurses with many years of work experience was due to a lack of present educational status

In the same line Roach \& Bhaskaranand, (2019) stated that a well-designed course on asthma 
management is an efficient scheme to improve public health nurses' knowledge and confidence on asthma care.

Ahmed et al., (2011) stated that self-management support from the care team is critical for improving chronic disease outcomes. Given the high volume of patients and time constraints during clinical visits, primary care physicians have limited time to teach and reinforce use of proven self-management strategies. Health information technology (HIT) has the potential to provide clinicians and a large number of patients with tools to support health behavior change.

III.Nurses' knowledge regarding immediate nursing care for patient with status asthmaticus Our finding revealed that majority of nurses had satisfactory level of knowledge about nursing care for patient with status asthmatics after training courses. We cannot ignore the big percent of unsatisfactory level that may be attributed to insufficient courses related to standards nursing care for patients with bronchial asthma in their curriculum of nursing education and also insufficient in-service training.

On the other hand Miller et al., (2015) found that the level of education affect the knowledge score about the status asthmatics. Marquis and Huston, (2009) reported that; each organization and profession must set standards and objectives to guide individuals and practitioner in performing safe and effective care.

In The present study we found that nurses knowledge about emergency nursing care for patients suffering from status asthmaticus increased after application of nursing education program especially observation of patient's oxygen saturation for 12-24 hours that in line with Sorour et al., (2015) who stated that in the Intensive Care The overall goals of -asthma management were to maintain normal pulmonary function. Also Wilkinson et al., (2016) illustrated in his study that the best position for patient suffering from respiratory problem is fowler position and that agree with our finding.

Additionally, In the present study nurses gave significant correct answer about pulse oximetry reading importance as an indication to normal tissue oxygenation after receiving the educational program the same finding wase reported by Turner, (2015) Who concluded that patient saturation and tissue oxygenation should be assessed by pulse oximetry.

The significant difference of the Nurses post - and pre education program answer about the Patient's need to oxygen intake as an immediate nursing management of status asthmaticus. Which is similar to what has been found by Chang et al., (2015).

Also in the present study, the nurses reported that the non -productive cough is the main sign of oxygen toxicity. Pasterkamp, and Zielinski, (2019) reported that the earliest sign of pulmonary oxygen toxicity is a mild irritation in the trachea that is made worse with deep inspiration. A mild cough develops next, followed by more severe irritation and cough until inspiration becomes quite painful and the cough becomes uncontrollable.

After the application of the educational program the majority of nurses have good answer about the correct dose of epinephrine that should be given to the client with asthma that need to be $0.1 \mathrm{mg}$. The same finding was reported by Andrews \& O'Brien (2014).

Concerning procedures that help in decreasing patient anxiety, the study showed that more than half of nurses recognized the steps of anxiety reduction technique and this is in agreement with Goodwin et al., (2014) findings.

Holgate \& Polosa (2006) stated that the complications of status asthmaticus included aspiration pneumonia, pneumothorax, respiratory failure, cardiac arrest and Hypoxic-ischaemic brain injury. Majority of nurses following the education program reported that respiratory failure, congestive heart failure and pneumothorax are the main complications of status asthmaticus in the current study.

The present study showed that the patients should be under observation to monitor vital signs for prevention of complications .In agreement with this Ramnath et al., (2007) reported the indication of hospitalization in both sudden and slower onset asthma exacerbations

\section{IV.Long-term management of patient with status asthmaticus}

The present study showed a statistical significant differences between pre-test and post-test regarding things that the patient must be avoided, Exercise which improve breathing and prevent asthma attack, Food that improve breathing and prevent asthma attack, and Food must be avoided, while there was no statistical significant difference regarding Methods of drug intake.

In agreement with these findings Teach et al., (2015) reported that the inhalation is the best method of asthma control.

Looking in the dangers things that the patient must avoid them, all studied nurses reported that; smoking and dust were the most common triggers of asthma. This finding disagreed with Guarnieri, \& Balmes (2014) who reported that viral infection and air pollution were the most common precipitating factors of asthma attack .

The majority of studied nurses in present study mentioned that; coughing and breathing exercises and yoga were useful to asthmatic patients. This was in accordance with França et al., (2015) who reported that physical and mental relaxation, improve posture, 
strengthen respiratory musculature, and develop more efficient patterns of breathing..

Similarly CDC, (2011) reported that asthma is an acute, reversible, usually self-terminating airway obstruction that develops during or after vigorous activity, reaches its peak 5 to10 minutes after stopping the activity, and usually stops in another 20 to 30 minutes.

As regarding to diet that had improve breathing functions and foods, which should be avoided to prevent asthma attack

In the present study, the majority of the studied nurses following the education program reported that milk must be avoided for asthmatic patients. In agreement with this Swedin et al., (2017) reported that Patients sensitive to food have higher rates of hospitalization and require more steroid medications to manage their asthma symptoms.

Calhoun, (2014) reported that patients milk allergy can react to a very small quantity of milk protein, including minor contamination and even inhalation of milk powder may develop asthma

Haby et al., (2013) reported that minute amounts of egg can result in asthma symptoms within minutes, including anaphylaxis. This is also seen after contact with egg through non-oral routes. Reactions may occur for the first time in a child who is given egg (Lee \& Bye, 2019). They also found that Soy is an insidious hidden allergen that may cause asthma symptoms and anaphylaxis.

(Grand \& Correia, 2015) reported that Peanuts allergy is one of the most common food allergies. It can cause asthma and anaphylaxis and leading to high mortality rates in many cases.

Mohamed, (2011) reported that Vitamin-C is the most extensively investigated antioxidant that reduce the risk of asthma, Lowering plasma and leukocyte concentration of vitamin- $\mathrm{C}$ has been associated with a high prevalence of asthma in adults patients. Supplementation with vitamin-C has been shown to decrease asthma severity and frequency

Devereux, et al., (2019) mentioned that; vitamin E: is found in fruits (apples and mangos) and vegetables, vegetable oils, meat, poultry, nuts, and eggs. There is evidence of the beneficial effects of vitamin-E on asthma. High vitamin-E, intake is associated with reduction in asthma incidence.

Chaffari, et al., (2014) found that Vitamin D deficiency may explain the asthma epidemic.

Christina, (2010) reported that asthmatics are typically deficient in vitamin-B complex (especially vitamin-B6 and B 12) and folic acid and supplementation of these subjects with multivitamins can help to improve asthma symptoms.

Regarding the current study, all nurses had unsatisfactory knowledge level in pre-test, while majority of them had satisfactory knowledge level in post-test with statistical significant difference. In addition, the mean score of knowledge was higher in post-test than in pre-test, with statistical significant difference.

Similarly, Timby (2005) reported that, teaching was a major aspect of the professional role, patient teaching has been recognized as an independent nursing function and effective health education depend on scientific base and cultural awareness. Education program has shown quality improvement in the inpatient family asthma education.

Beasley et al., (2016) confirm the importance of building a support system that included physicians and certified educators dedicated to the success of inpatient asthma care.

The present study showed that there was no statistical significant differences between mean scores of knowledge regarding age groups, level of education, years of experience, working in another place, years of experience in current place. While it was found that, the mean score of knowledge was higher in nurses who attended training courses. Attending training courses about immediate and long-term nursing management of patient with status asthmaticus help nurses to gain more knowledge about how to provide safe care and prevent or reduce complications that may occur.

Finally, it can be concluded that, developing and implementing the nursing educational program about immediate and long term nursing management of patient with status asthmaticus achieved its objectives by improving nurse's knowledge. The emergency and chest department nurses must constantly seek better ways to improve their care provided to the patient.

\section{Conclusions}

Based on findings of the present study, it can be concluded that

- It was concluded that nurses' knowledge regarding the nursing care of bronchial asthma were 93.3\% at satisfactory level. It was needed to be improved through implementation of proposed nursing care standards of bronchial asthma.

\section{Recommendations}

\section{For patients}

1. Patient as the center of any designed care plan should be aware and involved in all parts of his care plan.

2. Patient education is not only a verbal activity. Nurses should develop a written information guideline or manual booklet for asthmatic persons and give it to every patient and explain how to safely live after asthma attack and their feedback must be taken into consideration; and involving of 
patients' family in health education to increase patient's adherence with care plan and regimen.

\section{References}

1. Ahmed, S., Bartlett, S., Ernst, P., Paré, G., Kanter, M., Perreault, R., \& Tamblyn, R., (2011): Effect of a web-based chronic disease management system on asthma control and health-related quality of life: study protocol for a randomized controlled trial. Trials, 12 (1), P.P. 260

2. Albarraq, A., (2019): Assessment of caregivers' knowledge and behavior in the management of pediatric asthma in Jazan, Saudi Arabia. Assessment, 8(2), 98-104.

3. Ameen, M., \& Abdullah, S., (2017): Knowledge and attitude of nursing staffs about medical waste management in primary health care centres in ERBIL city, IRAQ. The Malaysian Journal of Nursing, 9(2), 58-63.

4. Andrews, K., \& O'Brien, M., (2014): Administering Medicines Developing Practical Nursing Skills, P.P. 187.

5. Antonioli, L., Blandizzi, C., Pacher, P., \& Haskó, G., (2019): The Purinergic System as a Pharmacological Target for the Treatment of Immune-Mediated Inflammatory Diseases. Pharmacological reviews, 71(3), P.P. 345-382.

6. Beasley, R., Semprini, A., \& Mitchell, E., (2015): Risk factors for asthma: is prevention possible?. The Lancet, 386(9998), P.P.10751085.

7. Calhoun, C., (2014): Chronic Airflow Limitation: Asthma COPD and Asthma COPD Overlap Syndrome (ACOS). Am J ResspirCrit Care Med; 7(11), P.P.79-94.

8. Centers for Disease Control and Prevention (CDC), (2011): Vital signs: asthma prevalence, disease characteristics, and self-management education_ United States, Morbidity and Mortality Weekly Report. Am J RespirCrit Care Med; 3(4), P.P. 3479-3491.

9. Chaffari, J., Ashrafi, H., Ranjbar, A., \&Nazari, Z., (2014): Vitamin E in children with asthma. N Engel J Med.A review, 2(2), http://doi.org/.

10. Chang, C., Guo, Z., He, B., \& Yao, W., (2015): Metabolic alterations in the sera of Chinese patients with mild persistent asthma: a GC-MS-based metabolomics analysis. Acta Pharmacologica Sinica, 36(11), P.P. 1356-1366.

11. Christina, J., (2010): Infant nutrition in the first year oflife: Tradition or science. Pediatric Crit Care Med 25(4), P.P.725-732.
12. David, Z., (2012): Severity of obstructive airways disease by age 2 years predicts asthma at 10 years of age. Am Rev Respir Dis; 6(2),P.P. 114-117.

13. Devereux, G., Craig, L., Seaton, A., \& Turner, S., (2019): Maternal vitamin D and E intakes in pregnancy and asthma to age 15 years: A cohort study. Pediatric pulmonology, 54(1), P.P. 11-19.

14. Fehrenbach, H., Wagner, C., \& Wegmann, M., (2017): Airway remodeling in asthma: what really matters. Cell and tissue research, 367(3), P.p. 551-569.

15. Flinter, M., Hsu, C., Cromp, D., Ladden, M., \& Wagner, E., (2017): Registered Nurses in Primary Care: Emerging New Roles and Contributions to Team-based Care in Highperforming Practices. The Journal of ambulatory care management, 40(4), 287.

16. França-Pinto, A., Mendes, F., de CarvalhoPinto, R., Agondi, R., Cukier, A., Stelmach, R., \& Carvalho, C., (2015): Aerobic training decreases bronchial hyperresponsiveness and systemic inflammation in patients with moderate or severe asthma: a randomised controlled trial. Thorax, thoraxjnl, P.P. 576.

17. George, M., Abboud, S., Pantalon, M., Sommers, M., Mao, J., \& Rand, C., (2016): Changes in clinical conversations when providers are informed of asthma patients' beliefs about medication use and integrative medical therapies. Heart \& Lung: The Journal of Acute and Critical Care, 45(1), P.P. 70-78.

18. Goodwin, R., Scheckner, B., Pena, L., Feldman, J., Taha, F., \& Lipsitz, J., (2014): A 10 -year prospective study of respiratory disease and depression and anxiety in adulthood. Annals of allergy, asthma \& immunology, 113(5), P.P. 565-570.

19. Grand, R., \&Correia, R., (2015): Association between Dietary Habits and Asthma Severity in Children. ClinExep Allergy; 23:58-68.

20. Guarnieri, M., \& Balmes, J., (2014).Outdoor air pollution and asthma. The Lancet, 383(9928), P.P.1581-1592.

21. Haby, Lattka E., Rzehak P., (2013): Genetic variation in polyunsaturated fatty acid metabolism and its potential relevance for human development and health. Matern Child Nutr; 7, P.P. 27-40

22. Hassan, O., \& El-awady, M., (2015): Prevalence Of Bronchial Asthma And Its Relation With Obesity Among Preparatory And Secondary School Students In BenhaCity ,Qalyobia Governorate. Med J Cairo Univers: 10(2), P.P. 31:2. 
23. Hewitt, R., Farne, H., Ritchie, A., Luke, E., Johnston, S., \& Mallia, P., (2016): The role of viral infections in exacerbations of chronic obstructive pulmonary disease and asthma. Therapeutic advances in respiratory disease, 10(2), P.P.158-174.

24. Holgate S., Polosa R., (2006): The mechanisms, diagnosis, and management of severe asthma in adults. Lancet. (9537), P.P. 780-93.

25. Irene L., Labuschagnea \& Evette van Niekerk South African. (2015): Family Practice; P.P. 13.

26. Koolwal, A., Koolwal, S., Sehajpal, R., \&Kapoor, H., (2014): Diet and asthma: An observational study. Indian Journal of Allergy, Asthma and Immunology, 28(2), P.P. 93-127.

27. Lee, A., \& Bye, M., (2019): Lung injury from hydrocarbon aspiration and smoke inhalation. In Kendig's disorders of the respiratory tract in children, pp. 626-633.

28. Louis, P., Helen, R., (2014): A pocket Guide for Physicians and Nurses. Journal of Clinical Nursing; 7(0), P.P. 47-56.

29. Marquis, L., \& Huston, J., (2009): Leader ship roles and management functions in nursing, $6^{\text {th }}$ ed., Lippincott, Hong Kong, p.371.

30. Miller, A., Breslin, M., Pineda, L., \& Fox, J., (2015): An asthma protocol improved adherence to evidence-based guidelines for pediatric subjects with status asthmaticus in the emergency department. Respiratory care, 60(12), p.p. 1759-1764.

31. Mohamed, R., (2011): Developing Postoperative care standards for patients who had drainage of chronic subdural hematoma, submitted for partial fulfillment of Master Degree in Medical and surgical Nursing Faculty of Nursing, Assiut University, P.P.36.

32. National Heart Lung and Blood Institute (MILBI), (2011): What is asthma? 19 (2), P.P.147-153.

33. Pasterkamp, H., \& Zielinski, D. (2019): The history and physical examination. In Kendig's Disorders of the Respiratory Tract in Children, pp. 2-25.

34. Qiu, B., Huang, L., \& Li, Y., (2017): health education for asthmatic patients and caregivers from nursing perspective, chapter (5), P.P. 134: 144

35. Ramnath V., Clark S., Camargo C., (2007): Multicenter study of clinical features of suddenonset versus slower-onset asthma exacerbations requiring hospitalization. Respir Care. 2007 Aug52(8)1, P.P. 13-20.

36. Roach, E., \& Bhaskaranand, N., (2019): Effectiveness of an Educational Package on
Health Promotion Behaviours of Mothers of Asthmatic Children in Karnataka, India: A Quasi Experimental Study. Indian Journal of Public Health Research \& Development, 10(8), 231236.

37. Saadeh, D., Salameh, P., Baldi, 1.,\&Baherison, C., (2015): Diet and Allergic Diseases among population Aged 0 to 18 years: Myth or Reality? Nutrients; 5(9), P.P. 33993423.

38. Shah, P., (2009): Nursing care plan for amputated patients, P.P. 66-70.

39. Silva, D., \& Moreira, A., (2017): Asthma and allergies. In Injuries and Health Problems in Football, Springer, Berlin, Heidelberg, pp. 541561.

40. Singh, B., (2017): Asthma and chronic obstructive pulmonary disorderphytomedicine. International Journal of Green Pharmacy (IJGP), 11(03), P.P.234

41. Smeltzer, S., (2010): Bruner and Suddarth's Textbook of Medical Surgical Nursing, chapter $5,12^{\text {lh }}$ edition, Lippincott Williams \& Wilkins. P.P. 620:630

42. Sorour, K., Vyas, P., Raval, D., Donovan, L., \& Vyas, A., (2015): Successful Treatment of Severe Asthma Exacerbation with Sevoflurane Inhalation in the Intensive Care Unit. J Anesth Crit Care Open Access, 3(2), P.P. 92.

43. Swedin, L., Saarne, T., Rehnberg, M., Glader, P., Niedzielska, M., Johansson, G., ...\& Catley, M., (2017): Patient stratification and the unmet need in asthma. Pharmacology \& therapeutics, 169, P.P. 13-34.

44. Teach, S., Gill, M., Togias, A., Sorkness, C., Arbes, S., Calatroni, A., \& Kercsmar, C., (2015): Preseasonal treatment with either omalizumab or an inhaled corticosteroid boost to prevent fall asthma exacerbations. Journal of Allergy and Clinical Immunology, 136(6), P.P. 1476-1485

45. Thenaruvi, M., Rachel, M.., \& Sandhiya, M., (2019): A study to assess the knowledge and quality of life of asthma among adult asthmatics in selected hospital, kelambakkam, kanchipuram district, tamilnadu. Paripex-Indian Journal Of Research, 8(3), P.P. 345

46. Timby B., (2005): Fundamental nursing skills and concept, 8th ed, Lippincott Williams. Pp.9095, 147-151.

47. Turner, C., (2015): Cerebral oximetry readings in the sitting position versus supine position for patients undergoing general anesthesia. The University of Southern Mississippi., Published by ProQuest LLC, P.P. 26. 
48. Vedanthan, P., Mahesh, P., \& Roy, S., (2016): Allergy-Asthma Practice: East vs. West. In Textbook of Allergy for the Clinician (pp. 457-470).

49. Wang, T., Tan, J., Xiao, L., \& Deng, R., (2017): Effectiveness of disease-specific selfmanagement education on health outcomes in patients with chronic obstructive pulmonary disease: an updated systematic review and metaanalysis. Patient education and counseling, 100(8), P.P. 1432-1446.

50. Wilkinson, J., Treas, L., Barnet, K., \& Smith, M., (2016): Procedure Checklists for Fundamentals of Nursing. FA Davis, P.P. 345 